JEL: F12, P42, Q13

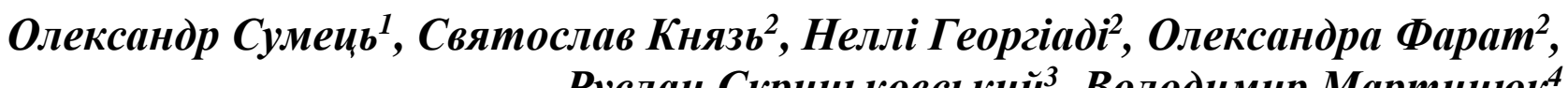
Руслан Скриньковський ${ }^{3}$ Володимир Мартинюк ${ }^{4}$

${ }^{1}$ Національний фармацевтичний університет
${ }^{2}$ Національний університет «Львівська політехніка»
${ }^{3}$ ЗВО «Львівський університет бізнесу та права»
${ }^{4}$ Університет економіки та інновацій
${ }_{1,2,3}$ Украйна
${ }^{4}$ Польщуа

\title{
МЕТОДИЧНИЙ ПІДХІД ДО ВИБОРУ ВАРІАНТІВ ЗАБЕЗПЕЧЕННЯ КОНКУРЕНТОСПРОМОЖНОСТІ ПІДПРИЕМСТВ У СИСТЕМІ РОЗВИТКУ АГРОКЛАСТЕРІВ
}

Мета. Метою виконаного дослідження є удосконалення методичного підходу до вибору варіантів забезпечення конкурентоспроможності підприємств у системі розвитку агрокластерів. Для досягнення иієї мети ідентифіковано факторні й результативні показники, на основі яких ухвалюватиметься рішення про прийнятність варіанта забезпечення конкурентоспроможності підприємства; конкретизовано критеріі задоволення значень факторних і результативних показників; формалізовано задачу вибору оптимального варіанта забезпечення конкурентоспроможності підприємства.

Методологія / методика / підхід. Під час виконаного дослідження застосовано методи систематизаиії та індукиії для критичного аналізу проблеми вибору варіантів забезпечення конкурентоспроможності підприємств у системі розвитку агрокластерів. Для формалізачії задачі вибору оптимального варіанта забезпечення конкурентоспроможності підприємства застосовано інструментарій дискретної математики та положення теорї формування інвестииійних портфелів. Для демонстрування прикладу застосування запропонованого методичного підходу до вибору варіантів забезпечення конкурентоспроможності підприємств у системі розвитку агрокластерів застосовано метод експертних оцінок. Вихідні експертні дані отримано на основі опитування керівників кластерів, які є учасниками Української начіональної технічної платформи «Агротехнічна платформа».

Результати. Обтрунтовано, що рішення про прийнятність варіанта забезпечення конкурентоспроможності підприємства в системі розвитку інноваційного кластера доцільно ухвалювати на основі урахування очікуваного прибутку підприємства та обсягу витрат коштів і часу, які необхідні для його отримання. Аргументовано, щзо рішення про оптимальний варіант забезпечення конкурентоспроможності підприємств необхідно приймати, враховуючи критеріальні значення, які можуть бути встановлені у певному діапазоні або задані, як максимальне або мінімальне значення. Доведено, щзо вибір найкращого варіанта забезпечення конкурентоспроможності підприємства можна звести до задачі пошуку оптимального розподілу інвестищійних ресурсів, спрямованих на забезпечення конкурентоспроможності підприємств у системі розвитку агрокластерів.

Орихінальність / наукова новизна. Удосконалено методичний підхід до вибору варіанта забезпечення конкурентоспроможності підприємства в системі розвитку агрокластера, який базується на застосуванні інструментарію дискретної математики та положень теорії формування інвестищійних портфелів, $i$, на відміну від існуючих, дозволяє 


поєднувати альтернативи, за якими може відбуватись забезпечення
конкурентоспроможності підприємства на будь-якому етапі його розвитку в системі агрокластера. Запропонований методичний підхід надає можливість оптимізувати розподіл інвестиційних ресурсів так, щзоб прийняті рішення забезпечували очікуваний рівень конкурентоспроможності підприємства.

Практична цінність / значущість. Ураховуючи те, щзо на цей момент часу в Україні функиіонують десятки агрокластерів, у межах яких функціонують сотні підприємств малого та середнього бізнесу, то очевидно, що фокус-група користувачів запропонованого методу є досить значною. Практична иінність застосування иъього методичного підходу полягає в можливості його використання підприємствами під час прийняття інвестиційних рішень, формування стратегії розвитку, розроблення тактичних моделей поведінки в періоди загострення конкуренції.

Ключові слова: конкурентоспроможність, підприємство, розвиток, агрокластер, прибуток, витрати.

Alexander Sumets ${ }^{1}$, Sviatoslav Kniaz ${ }^{2}$, Nelli Heorhiadi ${ }^{2}$, Olexandra Farat ${ }^{2}$,
Ruslan Skrynkovskyy ${ }^{3}$, Volodymyr Martyniuk ${ }^{4}$
${ }^{1}$ National University of Pharmacy
${ }^{2}$ Lviv Polytechnic National University
${ }^{3}$ Lviv University of Business and Law
${ }^{4}$ University of Economics and Innovation
${ }_{1,2,3}$ Ukraine $^{4}$
${ }^{4}$ Poland

\section{METHODICAL APPROACH TO THE SELECTION OF OPTIONS FOR ENSURING COMPETITIVENESS OF ENTERPRISES IN THE SYSTEM OF DEVELOPMENT OF AGRICULTURAL CLUSTERS}

Purpose. The purpose of the study is to develop a methodical approach of choosing options for ensuring the competitiveness of enterprises in the development of agricultural clusters. To achieve this goal, factor and performance indicators have been identified, on the basis of which a decision will be made on the acceptability of the option of ensuring the competitiveness of the enterprise; the criteria for satisfying the values of factor and performance indicators are specified; the task of choosing the optimal variant of ensuring the competitiveness of the enterprise is formalized.

Methodology / approach. During the study, the method of systematization and the method of induction were used for critical analysis of the problem of choosing options for ensuring the competitiveness of enterprises in the system of development of agricultural clusters. The tools of discrete mathematics and the provisions of the theory of investment portfolio formation are used to formalize the problem of choosing the optimal option for ensuring the competitiveness of the enterprise. To demonstrate an example of the application of the proposed methodological approach to the choice of options for ensuring the competitiveness of enterprises in the system of development of agricultural clusters, the method of expert assessments was used. The initial expert data were obtained on the basis of a survey of cluster leaders who are members of the Ukrainian National Technical Platform "Agrotechnical Platform".

Results. It is substantiated that the decision on the acceptability of the option of ensuring the competitiveness of the enterprise in the system of innovation cluster development must be made 
based on the expected profit of the enterprise and the amount of money and time required to obtain it. It is argued that the decision on the best option to ensure the competitiveness of enterprises should be made on the basis of criteria that can be set in a certain range or set as a maximum or minimum value. It is proved that the choice of the best option to ensure the competitiveness of the enterprise can be reduced to the task of finding the optimal distribution of investment resources aimed at ensuring the competitiveness of enterprises in the development of agricultural clusters.

Originality / scientific novelty. The methodical approach to the choice of option of ensuring the competitiveness of the enterprise in the system of agricultural cluster development has been improved. It is based on the application of discrete mathematics tools and the provisions of the theory of investment portfolio formation, and also allows you to combining alternatives that can ensure the competitiveness of the enterprise at any stage of its development in the agricultural cluster system. The proposed methodical approach allows optimizing the distribution of investment resources of enterprises so that the decisions taken provide the expected level of their competitiveness.

Practical value / implications. Today in Ukraine there are many agricultural clusters, within which hundreds of small and medium enterprises operate. Therefore, the focus group of users of the proposed method is quite significant. The practical value of this methodical approach lies in the possibility of its use by enterprises in making investment decisions, the formation of development strategies, the development of tactical models of behavior in periods of increased competition.

Key words: competitiveness, enterprise, development, agricultural cluster, profit, expenses.

Постановка проблеми. Зародження й розвиток агрокластерів $\epsilon$ унікальним економічним явищем, яке виникає тоді, коли складається певний комплекс умов, а саме: культурних, історичних і природно-кліматичних. Важливою обставиною $є$ також відсутність втручання в процеси формування кластерів уряду чи великого бізнесу. Наявність відповідних ринкових умов, високий рівень підприємницької активності, рівень освіти й тісна взаємодія із сферою науки сприяють зростанню конкурентоспроможності суб'єктів, що функціонують в агрокластерах. Вона полягає в тому, що окремі підприємства в межах одного агрокластера, конкуруючи між собою, із часом зустрічаються із проблемою обмеженості ринку та пошуку нових можливостей забезпечення конкурентоспроможності. Це вимагає поглиблення аналітичного інструментарію щодо акумулювання та вибору варіантів забезпечення їхньої конкурентоспроможності. Об'єднання підприємств та економічні «пули», сформовані великими зовнішніми інвесторами не варто розглядати як кластери, оскільки вони не завжди представляють інтереси малого та середнього бізнесу, більше того, вони не прив'язані до певного регіону, i, як наслідок, не завжди впливають на рівень життя на його території [1]. Для розв'язання проблеми негативного впливу великого бізнесу та урядової політики на зародження й розвиток кластерів у СС розробили та реалізовують концепцію формування Європейської технологічної платформи, на основі якої мала б бути створеною організаційно-комунікаційна система науково-практичної взаємодії суб'єктів малого та середнього бізнесу із інноваційними структурами. Нині у $\mathrm{CC}$ створено понад 30 технологічних платформ, широко відомими $є$ такі, як Advanced Engineering Materials and technologies (EuMAT), Advanced Construction Technology Platform (ECTP), European Nanoelectronics Initiative 
Advisory Council (ENIAC), European Space Technology Platform (ESTP), European Steel Technology Platform (ESTEP), Future Manufacturing technologies (Manufuture), Hydrogen and Fuel Cell technology Platform (HFP), Nanotechnologies for Medical Applications (Nanomedicine). У рамках цих ініціатив в Україні створено Українську національну технічну платформу «Агротехнічна платформа», яка об'єднує низку кластерів у сфері агробізнесу, а саме кластер «Харчові технології і промисловість», кластер «Агрохарчові біотехнології», кластер «Агроекологія», кластер «Безпека та якість їжі», кластер «Здоров'я рослин», кластер «Здоров'я тварин», кластер «Здоров'я людини», кластер «Нанотехнології», кластер «ІКТ», кластер «Ринки», кластер «Соціально-економічний», кластер «Координаційний». Слід визнати, завдяки практичній реалізації концепції Свропейських технологічних платформ кластери набули ознак системного розвитку (спільні цілі, стратегія їх досягнення, спільні комунікаціі), але попри організаційну раціональність інформаційно-комунікаційної взаємодії підприємств-учасників зазначених кластерів, нині в Україні, як і в СС, невирішеною залишається проблема науково обгрунтованого вибору варіантів забезпечення конкурентоспроможності підприємств у системі розвитку агрокластерів.

Аналіз останніх досліджень і публікацій. Огляд та аналіз наукової літератури дозволяє стверджувати, що різним аспектам розвитку кластерів, у тому числі агрокластерів приділено досить багато уваги. Проведені дослідження показали, що науковці в основному фокусують увагу на тому, що:

-кластер є винятково сприятливою формою активізування інноваційного розвитку. У цьому контексті доцільно згадати праці О.Фарат, М. Бець і М. Ливдар [1; 2], D. Audretsch i M. Feldman [3], П. Галвіна [4], Ф. Йогансена, С. Кернбрупа, Г. Андерсона, С. Рубаха [5], І. Кінаша, У. Андрусіва, О. Головні та I. Попадинця [6], F. Hermans, F. Geerling-Eiff, J. Potters, L. Klerkx [7], D. Aкullo, H. Maat i A. E. J. Wals [8];

-виникнення кластерів $€$ ознакою практичної реалізації положень концепції сталого розвитку. Про це детально викладено в працях J. Alroy [9]; Е. Попкової, Л. Шаховської, С. Абрамова [10], Н. Стоянець [11], М. Бігуса [12];

-регіони, які мають сільськогосподарську спеціалізацію, потребують підтримки держави для кластеризації агробізнесу, що певною мірою суперечить самій природі зародження та розвитку кластерів. Про це йдеться в працях D. Wardhan., R. Ihle i W. Hejman [13], Д. Артеменка [14], А. H. Berdiyev, M. K. Dustova [15].

Крім того, вченими велика увага приділяється економіко-управлінським аспектам формування та розвитку кластерів. У цьому напрямі відомими є праці О. Фарат, М. Бець, М. Ливдар [1; 2], С. Князя, Н. Мережко, Л. Кожушка, Р. Скриньковсього, С. Мороз, О. Калашник, Г. Карпенко, Ю. Туренко, А. Щебеля, О. Мрихіної, О. Павленко, Я. Богів, О. Кириченко, Б. Кушки, I. Пастирської, В. Дзвоника, С. Стасишина, Р. Русина-Гриника, Н. Мирощенко, А. Розмаріною, О. Головіної, Н. Галайка, Н. Георгіаді [16-21], Л. Вісільєвої 
[22], C. Comberg, V. K. Velamuri [23], Y. Ren, J. Miroslaw, J. Skibniewski \& Shaohua [24], Н. Вдовенко, В. Байдали, Н. Бурлаки та А. Діук [25], L. Prause, S. Hackfort, M. Lindgren [26], О. Шубравської, К. Прокопенко [27], I. Monastyrnaya, E. Gwenola, Y. Le Bris, B. Yannou, G. Petit [28], О. Будник [29], Т. Затонацької, О. Рожко, Н. Ткаченко [30], К. С. Saban Kumar, P. Arun Kumar Timalsina [31].

Ураховуючи наведене вище є підстави стверджувати, що більшість із проаналізованих наукових праць лише фрагментарно присвячені проблемам забезпечення конкурентоспроможності підприємств у системі розвитку агрокластерів, і містять в основному теоретичні, а не прикладні методичні рекомендації щодо вибору варіантів забезпечення конкурентоспроможності підприємств-учасників агрокластерів.

Метою статті $є$ удосконалення методичного підходу до вибору варіантів забезпечення конкурентоспроможності підприємств у системі розвитку агрокластерів. Для досягнення цієї мети необхідно:

- ідентифікувати факторні й результативні показники, на основі яких прийматиметься рішення про прийнятність варіанта забезпечення конкурентоспроможності підприємства;

- конкретизувати критерії задоволення значень факторних i результативних показників;

- формалізувати задачу вибору оптимального варіанта забезпечення конкурентоспроможності підприємства.

Виклад основного матеріалу дослідження. Ключовим питанням зазначеної проблеми є обгрунтований вибір певного варіанта забезпечення конкурентоспроможності підприємств у системі розвитку агрокластерів. Зважаючи на виключно загальні наукові принципи доцільно припустити, що за будь-яких умов суб'єкт підприємництва володіє певним набором рішень, усі 3 яких характеризуються відомими та невідомими змінними. До відомих змінних доцільно віднести час та витрати коштів, а до невідомих - результат понесених витрат, який може вимірюватись прибутком, обсягом реалізації, або, ураховуючи досліджувану проблематику, кількістю суб'єктів підприємництва у певному регіоні тощо. Цю змінну слід вважати невідомою, з огляду на те, що в момент планування ії можна тільки прогнозувати із певною точністю. 3 огляду на наведені припущення, представимо вектори вхідних даних у такій формі:

$$
C=\left[\begin{array}{c}
c_{1} \\
c_{2} \\
\ldots \\
c_{N}
\end{array}\right] ; T=\left[\begin{array}{c}
t_{1} \\
t_{2} \\
\ldots \\
t_{N}
\end{array}\right] ; R=\left[\begin{array}{c}
r_{1} \\
r_{2} \\
\ldots \\
r_{N}
\end{array}\right],
$$

де $C, T, R$ - відповідно вектори вхідних відомостей значень параметрів витрат коштів і часу, а також результату (очікуваного прибутку).

Нижніми індексами позначено альтернативні варіанти вхідних даних. Оскільки в умовах невизначеності необхідною $\epsilon$ альтернативність у забезпеченні конкурентоспроможності підприємства, то доцільно створити 


\section{Agricultural and Resource Economics: International Scientific E-Journal}

http://are-journal.com

окремий тактичний план, який включатиме два і більше варіантів, звісно, якщо особливості їхньої реалізації дозволяють це.

Зважаючи на логіку поставленої задачі, опишемо іiі на основі такого виразу:

$$
R=f(C, T) .
$$

Як бачимо з виразу (2), результат завжди слід розглядати, як функцію від витрат часу та коштів, записану у векторній формі. Оскільки під час реалізації будь-якого плану дій на його результат впливають певні чинники, які на етапі моделювання можуть бути не враховані, то це вимагає врахування похибки. Алгебраїчно функція (2), під час реалізації певного етапу забезпечення конкурентоспроможності підприємств у системі розвитку агрокластерів, може бути представлена так:

$$
r_{i}=f\left(c_{i}, t_{i}\right),
$$

де $i$ - індекс обраного варіанта.

Серед математичних функцій, які можливо взяти за основу, слід вибрати ті, які відповідають таким вимогам:

1) функція придатна для опису прискореної або уповільненої зміни показників у часі;

2) значення функції визначені на площині від нуля до нескінченності;

3) функція є простою для застосування на практиці.

Постає завдання прийняти рішення на користь степеневих залежностей, чи відповідають вони представленим вище вимогам. Їхнє застосування є простим на практиці, оскільки отримання степеневих коефіцієнтів може відбуватись на основі методу найменших квадратів. Після отримання рівняння залежності, необхідним $\epsilon$ визначити оптимальну комбінацію «тривалості-вартості» для «оптимального» варіанту. Вибір буде відбуватися між тими варіантами, параметри реалізації яких найбільш наближені до «оптимальних». Проте, найважливішою $\epsilon$ не так проблема вирішення багато-параметричної оптимізаційної задачі, що може бути виконано на основі звичайного перебору, або дослідження отриманої функції, а вибір критеріальних значень, які можуть бути встановлені у певному діапазоні або задані, як максимальне або мінімальне значення. Вибір між цими варіантами критеріальних цілей оптимізаційної задачі залежить від показників, на основі яких вимірюється результат від реалізації певного варіанта забезпечення конкурентоспроможності підприємств у системі розвитку агрокластерів. Варто зауважити, якщо обирати максимальне або мінімальне значення, то очевидним $\epsilon$ те, що деякі задачі не матимуть розв'язків, оскільки логічним $\epsilon$ те, що тривалість і вартість будуть також максимальні.

Важливим питанням, на яке потрібно дати відповідь, це те, чи можливим $\epsilon$ виконання кількох варіантів паралельно? Паралельна реалізація може бути дослідженою 3 точки зору формування оптимальної структури розподілу альтернатив. Вирішення цієї проблеми уже $є$ в науковій теорії інвестицій та 
може бути застосовано для моделювання альтернативних варіантів забезпечення конкурентоспроможності підприємств у системі розвитку агрокластерів.

Для початку розглянемо спосіб моделювання, який базується на прийнятті рішення між абсолютно альтернативними варіантами із забезпечення конкурентоспроможності підприємств у системі розвитку агрокластерів. У такому випадку на кожному із етапів буде прийматися рішення про вибір між кількома альтернативними варіантами, які заплановано не втілювати паралельно. Це приводить до того, що процес реалізації повного варіанта із забезпечення конкурентоспроможності підприємств у системі розвитку агрокластерів може бути описаний у формі певного «дерева» відомого в теорії дискретної математики, як граф. Приклад наведено на рис. 1.

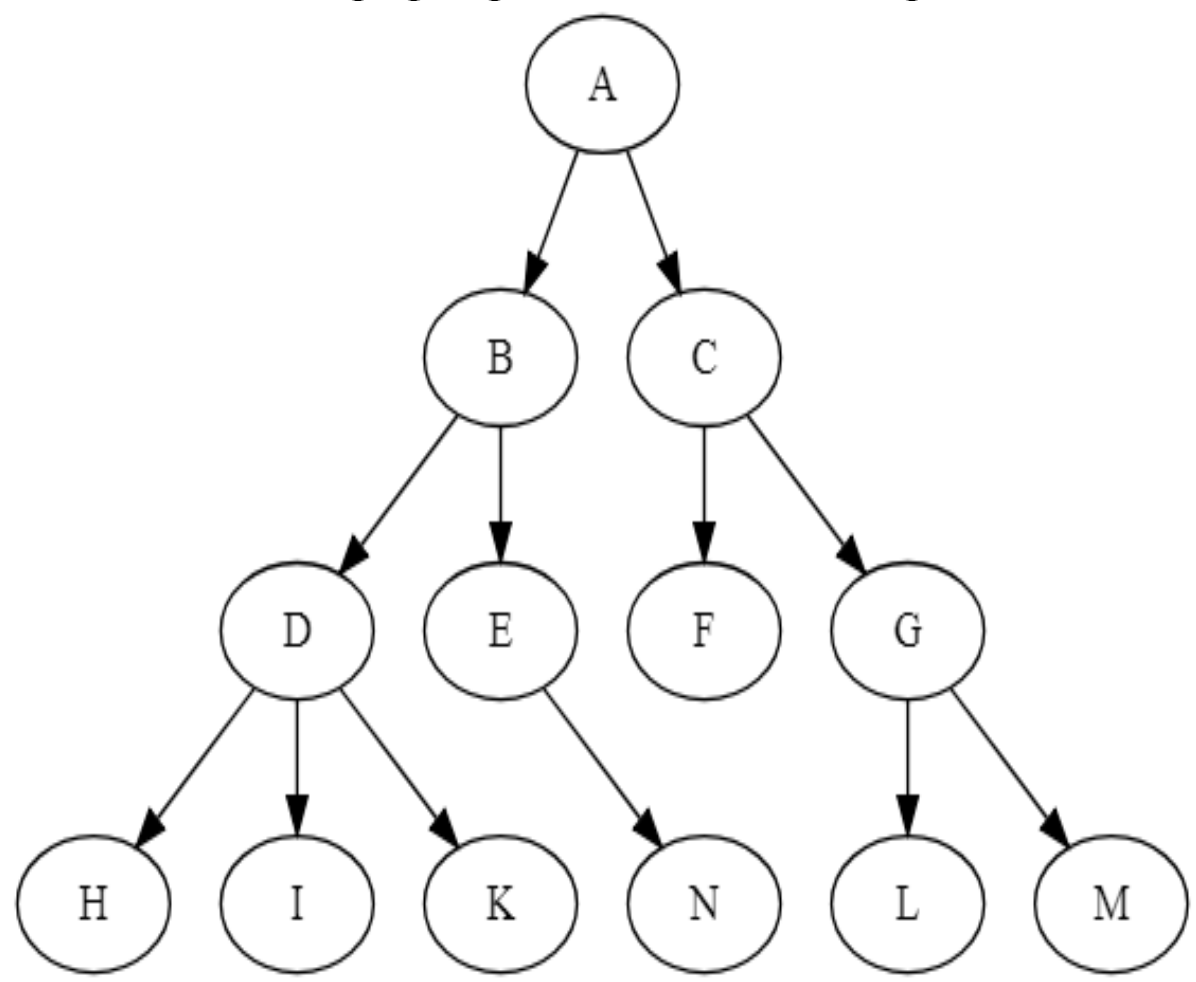

Рис. 1. Приклад кореневого графу реалізації альтернативних варіантів із забезпечення конкурентоспроможності підприсмств у системі розвитку агрокластерів

Джерело: побудовано авторами.

Такий граф завжди має один корінь, або вершину, з якої виходять усі «гілки». Прийняття рішення стосовно того, який варіант «С» чи «В» $\epsilon$ оптимальним, базується на врахуванні актуальної інформації та визначення того варіанту, який є більш дешевшим і коротшим у часі. Хоча, як мінімум, один оптимальний шлях проходження графа завжди $\epsilon$, все ж не варто стверджувати, що майбутній варіант із забезпечення конкурентоспроможності підприємств $\epsilon$ визначеним (відомим), оскільки доцільним є врахування нової актуальної інформації та перебудовування рівняння з метою отримання більш точних відомостей щодо визначення оптимального варіанта на кожному із етапів графа. 


\section{Agricultural and Resource Economics: International Scientific E-Journal} http://are-journal.com

Запишемо оптимізаційну задачу на кожному із етапів прийняття рішення так:

$$
\left\{\begin{array} { l } 
{ r = f ( c , t ) , c \in C ; t \in T ; } \\
{ r \rightarrow \operatorname { m i n } ( \operatorname { m a x } ) . }
\end{array} \Rightarrow \left\{\begin{array}{l}
r=a_{0} c^{a_{1}} t^{a_{2}}, c \in C ; t \in T ; \\
r \rightarrow \min (\max ),
\end{array}\right.\right.
$$

де ${ }^{a_{0}}, a_{1}, a_{2}$ - степеневі коефіцієнти, част. од.;

$C$ - вектор значень вартості реалізації кожного із варіантів на певному етапі проходження графа;

$T$ - вектор значень тривалості реалізації кожного із варіантів на певному етапі;

$r$ - показник, на основі якого вимірюється результат проходження певного етапу.

Таким чином, вибір між окремими варіантами забезпечення конкурентоспроможності підприємств у системі розвитку агрокластерів може бути описано на основі графа із необмеженою кількістю шляхів досягнення прийнятного результату. Цей процес має відбуватись із постійним оновленням інформації та перебудовуванням степеневого рівняння, що дозволить збільшити його точність і статистичну значущість. Отже, на основі використання такого підходу можливим є досягнення оптимального результату під час реалізації обраного варіанта забезпечення конкурентоспроможності підприємств у системі розвитку агрокластерів.

Побудова степеневого рівняння на початковому етапі реалізації графа має відбуватись на основі інформації, зібраної шляхом аналізування власного досвіду реалізації таких варіантів забезпечення конкурентоспроможності підприємств у минулому або на основі врахування наявної практики інших підприємств. Це дає можливість сформувати ряд ретроспективних даних, які доцільно застосувати для отримання першого рівняння. На кожному із етапів проходження графа дані доповнюються новими відомостями, що покращує якість рівняння та дозволяє врахувати екстремальні коливання певних показників, значення яких зумовлені впливом непередбачуваних чинників. Отримання степеневого рівняння можливе на основі застосування методу найменших квадратів, що $\epsilon$ можливим шляхом логарифмування вхідних відомостей та побудови логарифмічної залежності.

Описаний вище метод вибору між кількома варіантами базується на виборі між даними, представленими у формі матриць. Проте, на практиці може виникнути необхідність вирішення цієї задачі без чітко заданих вхідних даних. Так, забезпечення конкурентоспроможності підприємств може бути реалізованим шляхом використання максимального або мінімального бюджету коштів. Між цими двома «точками» може існувати нескінченне число варіантів. Відповідь на питання про те, який із варіантів $є$ оптимальним доцільно дати на основі дослідження степеневої функції на предмет визначення умов, за яких функція $\epsilon$ зростаючою. Зростання функції може відбуватись прискорено, уповільнено або рівномірно. Рівномірне зростання відповідає лінійній функції, прискорене зростання вказує на те, що результативність діяльності 
підприємства в системі розвитку агрокластера із часом зростає все швидшими темпами. Це свідчить про виникнення синергії та ефективного врахування досвіду й знань підприємства-учасника агрокластера. Ураховуючи це, необхідним є дослідження не зміни функції, а зміни приростів. Проаналізуємо степеневу залежність на предмет визначення того, за яких умов вона $\epsilon$ прискорено зростаючою. Для цього диференціюємо цю функцію за змінною часу та витрат:

$$
\begin{aligned}
& \frac{f(c, t)}{\partial^{2} c}=\frac{\left(a_{o} c^{a_{1}} t^{a_{2}}\right)}{\partial^{2} c}=\frac{\left(a_{o} a_{1} c^{a_{1}-1} t^{a_{2}}\right)}{\partial c}=a_{o} a_{1}\left(a_{1}-1\right) c^{a_{1}-2} t^{a_{2}} \\
& \frac{f(c, t)}{\partial^{2} t}=\frac{\left(a_{o} c^{a_{1}} t^{a_{2}}\right)}{\partial^{2} c}=\frac{\left(a_{o} a_{2} c^{a_{1}} t^{a_{2}-1}\right)}{\partial c}=a_{o} a_{2}\left(a_{2}-1\right) c^{a_{1}} t^{a_{2}-2} .
\end{aligned}
$$

Розв’яжемо систему нерівностей:

$$
\begin{aligned}
& \left\{\begin{array}{l}
a_{o} a_{1}\left(a_{1}-1\right) c^{a_{1}-2} t^{a_{2}}>0 ; \\
a_{o} a_{2}\left(a_{2}-1\right) c^{a_{1}} t^{a_{2}-2}>0 ;
\end{array}\right. \\
& \left\{\begin{array}{l}
c^{a_{1}-2}>0 \\
t^{a_{2}-2}>0 .
\end{array}\right. \\
& \left\{\begin{array}{l}
a_{1}>2 \\
a_{2}>2
\end{array}\right.
\end{aligned}
$$

На основі системи нерівностей (6) доходимо висновку: якщо алгебраїчна сума обох степеневих коефіцієнтів $є$ меншою двох, степенева функція зростає не прискорено. Логічним $\epsilon$ те, що найбільш успішним співвідношенням «тривалості-вартості»є те, яка алгебраїчна сума степеневих коефіцієнтів буде більшою рівною 1. Таким чином, визначено, за яких значень степеневих коефіцієнтів, можливим $є$ виникнення синергічних ефектів у «середині» певного агрокластера, що дозволяє приймати раціональне рішення на предмет вибору між деякими варіантами реалізації стратегії його розвитку.

Для підсумування описаного вище інструментарію конкретизуємо етапи вибору варіанта забезпечення конкурентоспроможності підприємств у системі розвитку агрокластерів:

•виникнення необхідності моделювання варіанта із забезпечення конкурентоспроможності підприємств у системі розвитку;

•формулювання цілей;

•вибір показника, на основі якого вимірюється стан виконання цілей;

•формування варіантів послідовності досягнення поставлених цілей;

-збір попередньої інформації стосовно тривалості та вартості та результатів на кожному із етапів;

•математичне моделювання та вибір між першими альтернативними варіантами;

•урахування актуальної інформації та повторне моделювання й прийняття рішення на наступних етапах; 


\section{Agricultural and Resource Economics: International Scientific E-Journal} http://are-journal.com

•досягнення завершального етапу та перевірка, чи досягнуті поставлені цілі.

Як бачимо, вибір варіанта забезпечення конкурентоспроможності може складатись із низки етапів, які базуються на формуванні графу типу кореневого дерева та прийняття рішення щодо оптимального варіанта на кожному із етапів проходження графа.

Вибір рішення на основі такого графа інколи потребує повернення на попередній етап, що зумовлено можливими змінами у зовнішньому середовищі, або виникненням необхідності радикального перегляду обраного варіанта. 3 огляду на це, проходження графа може тривалий час відбуватись не прогнозовано. Проте, чим довше відбувається цей процес, тим більше інформації доцільно зібрати, тим більш точними та статистично значущими будуть математичні моделі, тим більш раціональними будуть рішення на кожному із етапів. Ураховуючи це, пропонована технологія вибору базується на врахуванні досвіду та знань суб'єктів процесу моделювання.

Проведені дослідження дозволяють стверджувати, що послідовність моделювання на засадах вибору альтернативних варіантів забезпечення конкурентоспроможності потребує прийняття рішення між двома або більше взаємовиключними варіантами, що не завжди є коректним, оскільки інколи можливим є втілення кількох альтернатив одночасно. Тоді прийняття рішення відбувається не на засадах вибору, а на засадах розподілу наявних ресурсів між певним набором варіантів, тобто рішення задачі зводиться до формування оптимальної структури. За таких умов слід відштовхуватися від того, що основою є тільки один показник - дохідність. Рівень ризику розраховується, як дисперсія дохідності. 3 точки зору вирішення означеної в цьому випадку задачі, необхідним $є$ вибір показника, на основі якого можливим є оцінити рівень ризиковості кожного із варіантів. Для вибору цього показника слід враховувати доступність ретроспективних даних. Кожен із пропонованих варіантів може бути розглянутий на предмет результатів, які від нього слід очікувати протягом певного періоду часу. Це дозволяє розраховувати дисперсію значень цього показника і тим самим визначити, який iз варіантів $є$ найменш ризиковим. Такий підхід не завжди є можливим і має опиратись на наявність значного обсягу ретроспективних даних, проте він дозволяє уникнути альтернативності.

Задачу пошуку оптимальної структури розподілу ресурсів опишемо так:

$$
\left\{\begin{array}{l}
w_{1}+w_{2}+w_{3}+\ldots+w_{N}=1, \\
w_{1} r_{1}+w_{2} r_{2}+w_{3} r_{3}+\ldots+w_{N} r_{N}=r_{P}, \\
2 w_{1} \operatorname{Var}\left(r_{1}, r_{1}\right)+2 w_{2} \operatorname{Cov}\left(r_{1}, r_{2}\right)+2 w_{3} \operatorname{Cov}\left(r_{1}, r_{3}\right)+\ldots+2 w_{N} \operatorname{Cov}\left(r_{1}, r_{N}\right)-\kappa_{1} r_{1}-\kappa_{2}=0, \\
\ldots \\
2 w_{1} \operatorname{Cov}\left(r_{N}, r_{1}\right)+2 w_{2} \operatorname{Cov}\left(r_{N}, r_{2}\right)+2 w_{3} \operatorname{Var}\left(r_{N}, r_{3}\right)+\ldots+2 w_{N} \operatorname{Cov}\left(r_{N}, r_{N}\right)-\kappa_{1} r_{N}-\kappa_{2}=0,
\end{array}\right.
$$

де $w_{1}, \ldots, w_{N}$ - частки ресурсів у загальній структурі наявних варіантів (портфеля варіантів), част. од.; 


\section{Agricultural and Resource Economics: International Scientific E-Journal}

$r_{1}, \ldots, r_{N}$ - значення показника, на основі якого вимірюється результат втілення кожного із варіантів, ум. од.;

$r_{P}$ - зважений середній результат, ум. од.;

Var - варіація показника результативності;

Cov - коваріація показника результативності;

$N$ - кількість варіантів у певному портфелі;

$\kappa_{1}, \kappa_{2}$ - добутки Лагранжа, випадкові числа, які не відіграють жодної ролі й необхідні тільки для того, щоб звести системи лінійних рівнянь до однорідної форми.

Представлену вище систему лінійних рівнянь доцільно звести до матричної форми:

$$
K=\left[\begin{array}{cccccc}
1 & 1 & \ldots & 1 & 1 & 1 \\
r_{1} & r_{2} & \ldots & r_{N} & 1 & 1 \\
\operatorname{Var}\left(r_{1}, r_{1}\right) & \operatorname{Cov}\left(r_{1}, r_{2}\right) & \ldots & \operatorname{Cov}\left(r_{1}, r_{N}\right)-r_{1} & 1 \\
\operatorname{Cov}\left(r_{2}, r_{1}\right) & \operatorname{Var}\left(r_{2}, r_{2}\right) & \ldots & \operatorname{Cov}\left(r_{2}, r_{N}\right)-r_{2} & 1 \\
\ldots & \ldots & \ldots & \ldots & \ldots & \ldots \\
\operatorname{Cov}\left(r_{N}, r_{1}\right) & \operatorname{Cov}\left(r_{N}, r_{1}\right) & \ldots & \operatorname{Cov}\left(r_{N}, r_{N}\right)-r_{N} & 1
\end{array}\right], X=\left[\begin{array}{c}
w_{1} \\
w_{2} \\
w_{3} \\
\ldots \\
w_{N} \\
\kappa_{1} \\
\kappa_{2}
\end{array}\right], Y=\left[\begin{array}{c}
1 \\
r_{p} \\
0 \\
\ldots \\
0
\end{array}\right], X=K^{-1} \times Y .
$$

Таким чином, рішення може бути отримане шляхом не складних математичних маніпуляцій над вхідними даними. Це доводить, що пропонований метод $є$ простим для реалізації на практиці. Розрахунок оптимальної структури можливий на кожному із етапів проходження графа, що дає змогу перерозподілити ресурси найбільш оптимальним чином. Проте, слід зауважити, що процес математичного моделювання спирається на великі масиви ретроспективних відомостей і може бути реалізований тільки на основі наявності актуальної, повної та достовірної інформації. В умовах іiі відсутності доцільним є застосувати суб’єктивні методи, такі як експертне опитування тощо. Комбінування обох варіантів проходження дерева варіантів забезпечення конкурентоспроможності підприємств у системі розвитку агрокластерів дає змогу приймати раціональні рішення на кожному із етапів проходження цього графа.

Для демонстрування прикладу застосування цього методу оберемо один із найбільш розвинутих кластерів - «Агроекологія», який є одним із учасників Української національної технічної платформи «Агротехнічна платформа», що створена за підтримки Європейської дослідницької Консультативної ради (European Research Advisory Board, EURAB). Нині кластер «Агроекологія» об’єднує наукові та громадські організації, а також підприємства, зокрема: Інститут агроекології і природокористування НААН, Інститут водних проблем $\mathrm{i}$ меліорації НААН, Інститут кормів та сільського господарства Поділля, Інститут сільськогосподарської мікробіології та агропромислового виробництва НААН, Інститут цукрових буряків та енергетичних культур НААН, Біосферний 
заповідник «Асканія-Нова» НААН, Державне підприємство «Дніпрокосмос», Державна екологічна академія післядипломної освіти та управління, ТОВ «Екоплан», ТОВ «Перлина», ТОВ «Органічний сад», ГО «Екологія дитинства», Компанія «Біоінвест», ВГО «Асоціація агроекологів України», НВО «Екотех», Асоціація «Біолан», СП «Гідротехнології», НВП «Іригаційні системи».

Для забезпечення конкурентоспроможності підприємств у кластері «Агроекологія», відбувається паралельна реалізація двох векторів, а саме: розвиток системи логістики та науково-технічних досліджень в агросекторі. Процес реалізації заходів у межах цих векторів містить низку рішень, які приймаються часто індивідуально, та які, по суті, $\epsilon$ довгостроковою інвестицією у розвиток агробізнесу. Оцінювання ефективності заходів щодо забезпечення конкурентоспроможності в межах зазначених векторів $є$ складним завданням, проте його можна виконати аналізуючи поточні та ретроспективні дані, застосовуючи вищеописану технологію формування інвестиційних портфелів, яка базується на урахуванні обсягу й структури витрат на розвиток системи логістики та науково-технічних досліджень в агросекторі. Тоді очікуваний прибуток одного з підприємств кластера «Агроекологія» може бути оцінений на основі наявних ретроспективних відомостей щодо отримуваного прибутку із урахуванням умовних перспективних відомостей, які стосуються реалізації заходів у межах кожного із зазначених векторів забезпечення конкурентоспроможності. Вихідні дані НВО «Екотех» наведено в табл. 1.

Таблиия 1

Вихідні дані стосовно моделювання варіантів забезпечення конкурентоспроможності НВО «Екотех» у системі розвитку кластера «Агроекологія», тис. грн.

\begin{tabular}{|c|c|c|}
\hline \multirow{2}{*}{ Роки } & \multicolumn{2}{|c|}{ Об'єкти інвестування } \\
\cline { 2 - 3 } & Системи логістики в агросекторі & $\begin{array}{c}\text { Науково-технічні дослідження в } \\
\text { агросекторі }\end{array}$ \\
\hline 2010 & 99,50 & 99,50 \\
\hline 2011 & 124,25 & 124,25 \\
\hline 2012 & 161,50 & 161,50 \\
\hline 2013 & 210,00 & 210,00 \\
\hline 2014 & 252,25 & 252,25 \\
\hline 2015 & 290,00 & 290,00 \\
\hline 2016 & 326,00 & 326,00 \\
\hline 2017 & 359,75 & 359,75 \\
\hline 2018 & 414,44 & 402,37 \\
\hline 2019 & 454,38 & 441,15 \\
\hline 2020 & 494,32 & 479,93 \\
\hline 2021 & 534,27 & 518,71 \\
\hline 2022 & 574,21 & 557,49 \\
\hline 2023 & 614,15 & 596,27 \\
\hline 2024 & 654,10 & 635,05 \\
\hline 2025 & 694,04 & 673,83 \\
\hline
\end{tabular}

Джерело: побудовано авторами, умовні дані сформовано за такими припущеннями: 1) 2010-2020 рр. використано реальні фактичні дані управлінської звітності НВО «Екотех»; 
2) 2021-2025 рр. дані приведено на основі застосування рівняння тренду та врахування експертної думки про те, що якісна система освіти змогла би пришвидшити розвиток кластеру щонайменше на $5 \%$. У ролі експертів виступали керівники підприємств, які $\epsilon$ учасниками агрокластерів. При похибці - 0,15 і довірчій імовірності - 0,95, опитано 34 респонденти. Респондентів обирали за такими критеріями - наявність профільної освіти, три роки досвіду роботи на керівній посаді, згода брати участь в експертному дослідженні.

На основі відомостей табл. 1, розрахуємо коваріаційну матрицю. Результати наведено в табл. 2.

Таблиия 2

Результати моделювання варіантів забезпечення конкурентоспроможності

НВО «Екотех» у системі розвитку кластера «Агроекологія», тис. грн

\begin{tabular}{|l|c|c|}
\hline \multicolumn{1}{|c|}{ Об’єкти інвестування } & $\begin{array}{c}\text { Системи логістики в } \\
\text { агросекторі }\end{array}$ & $\begin{array}{c}\text { Науково-технічні дослідження в } \\
\text { агросекторі }\end{array}$ \\
\hline $\begin{array}{l}\text { Системи логістики в } \\
\text { агросекторі }\end{array}$ & 33336,58 & 33336,58 \\
\hline $\begin{array}{l}\text { Науково-технічні дослідження } \\
\text { в агросекторі }\end{array}$ & 33336,58 & 31966,29 \\
\hline
\end{tabular}

Джерело: побудовано авторами.

Запишемо систему лінійних рівнянь задачі пошуку оптимальної структури розподілу коштів між обома досліджуваними варіантами забезпечення конкурентоспроможності НВО «Екотех» у системі розвитку кластера «Агроекологія»:

$$
\left\{\begin{array}{l}
w_{1}+w_{2}=1 \\
w_{1} 391,07+w_{2} 383,003=387,04 \\
w_{1} 33336,58+w_{2} 33336,58-\kappa_{1} 391,07-\kappa_{2}=0 \\
w_{1} 33336,58+w_{2} 31966,29-\kappa_{1} 383,003_{2}-\kappa_{2}=0
\end{array}\right.
$$

Після розв'язання системи лінійних рівнянь, отримуємо що, розподіл інвестиційних ресурсів слід здійснити таким чином:

- системи логістики в агросекторі - $51 \%$;

•науково-технічні дослідження в агросекторі - $49 \%$.

Як наслідок, на основі застосування запропонованого вище інструментарію показано, що два 3 векторів забезпечення конкурентоспроможності НВО «Екотех» у системі розвитку кластера «Агроекологія» мають практично однакову вагомість. Це дозволяє прийняти оптимальне рішення стосовно розподілу інвестиційних ресурсів на реалізацію заходів із забезпечення конкурентоспроможності НВО «Екотех» у системі розвитку кластера «Агроекологія».

Висновки. Обгрунтовано, що вибір оптимального варіанта забезпечення конкурентоспроможності може відбуватися на основі формування графа типу кореневого дерева й повинен передбачати можливість прийняття рішення щодо оптимального варіанта на кожному етапі проходження графа. У результаті проведених досліджень доведено, що рішення про оптимальний варіант забезпечення конкурентоспроможності підприємств у системі розвитку 


\section{Agricultural and Resource Economics: International Scientific E-Journal}

http://are-journal.com

агрокластерів необхідно приймати на основі урахування критеріальних значень, які можуть бути встановлені у певному діапазоні або задані, як максимальне або мінімальне значення. Вибір між цими варіантами критеріальних цілей оптимізаційної задачі залежить від показників, на основі яких вимірюється результат від реалізації певного варіанта забезпечення конкурентоспроможності. На результативні показники функціонування підприємств у системі розвитку агрокластерів впливають витрати коштів і часу на реалізацію того чи іншого варіанта забезпечення конкурентоспроможності. Практичне застосування удосконаленого методичного підходу дозволить підприємствам, які функціонують у системі агрокластерів, обирати оптимальні рішення щодо розподілу інвестиційних ресурсів, призначених для забезпечення конкурентоспроможності підприємств.

Подальші дослідження доцільно проводити в напрямі урахування впливу суб'єктивних чинників на забезпечення конкурентоспроможності підприємств у системі розвитку агрокластерів, а також впливу цих чинників на ризиковість використання інвестиційних ресурсів підприємств.

\section{Список використаних джерел}

1. Фарат O. Теоретико-методологічні підходи до забезпечення конкурентоспроможності суб'єктів підприємництва на засадах розвитку інноваційних кластерів: моногр. Львів: Вид-во Львівської політехніки, 2019. $224 \mathrm{c}$.

2. Farat O., Bets M. Formation of the information support for the entities of management by the development of innovation clusters. Baltic Journal of Economic Studies. 2018. Vol. 4. No. 2 Pp. 249-253. https://doi.org/10.30525/2256-0742/20184-2-249-253.

3. Farat O., Lyvdar M. Elaboration of technology for implementing of organizational solutions on the innovative clusters development. Baltic Journal of Economic Studies. 2019. Vol. 5. No. 3. Pp. 207-212. https://doi.org/10.30525/22560742/2019-5-3-207-212.

4. Audretsch D. B., Feldman M. P. Innovative clusters and the industry life cycle. Review of Industrial Organization. 1996. No.11. Pp. 253-273. https://doi.org/10.1007/BF00157670.

5. Galvin P. Local government, multilevel governance, and cluster based innovation policy: economic cluster strategies in Canada's city regions. Canadian Public Administration. 2019. Vol. 62. Is. 1. Pp. 122-150. https://doi.org/10.1111/capa.12314.

6. Johansen F. R., Kerndrup S., Andersson G., Rubach S. A view of clustering as emergent and innovative processes. Industry and Innovation. 2020. Vol. 27. Is. 4. Pp. 390-460. https://doi.org/10.1080/13662716.2020.1718618.

7. Kinash I., Andrusiv U., Golovnia O., Popadynets I. Aspects of the formation and development of innovation infrastructure in Ukraine. Management Science Letters. 2019. Vol. 9. Pp. 2403-2414. https://doi.org/10.5267/j.msl.2019.7.015.

8. Hermans F., Geerling-Eiff F., Potters J., Klerkx L. Public-private partnerships 
as systemic agricultural innovation policy instruments - assessing their contribution to innovation system function dynamics. NJAS - Wageningen Journal of Life Sciences. 2019. Vol. 88. Pp. 76-95. https://doi.org/10.1016/j.njas.2018.10.001.

9. Akullo D., Maat H., Wals A. E. J. An institutional diagnostics of agricultural innovation; public-private partnerships and smallholder production in Uganda. NJAS - Wageningen Journal of Life Sciences. 2019. Vol. 84. Pp.6-12. https://doi.org/10.1016/j.njas.2017.10.006.

10. Alroy J. Discovering biogeographic and ecological clusters with a graph theoretic spin on factor analysis. Ecography. 2019. Vol. 42. Is. 9. Pp. 1504-1513. https://doi.org/10.1111/ecog.04464.

11. Popkova E. G., Shakhovskaya L. S., Abramov S. A., Natsubidze A. S. Ecological clusters as a tool of improving the environmental safety in developing countries. Environment, Development and Sustainability. 2016. No. 18. Pp. 10491057. https://doi.org/10.1007/s10668-015-9685-3.

12. Стоянець Н. Регіональні кластери як структурні ланки сталого розвитку національної економіки. Agricultural and Resource Economics. 2017. Vol. 3. No. 2. Pp. 132-144. https://doi.org/10.22004/ag.econ.260672.

13. Бігус М. М., Голікова С. Д. Кластеризація як перспектива розвитку міжнародного туризму та активізатор економіки в Україні. Науковий вісник НЛТУ Украӥни. Серія економічна. 2017. Вип. $27 . \quad$ № 2. С. 48-52. https://doi.org/10.15421/40270209.

14. Wardhana D., Ihle R., Heijman W. Agro-clusters and rural poverty: a spatial perspective for West Java. Bulletin of Indonesian Economic Studies. 2017. Vol. 53. Is. 2. Pp. 161-186. https://doi.org/10.1080/00074918.2017.1298722.

15. Артеменко Д. А. Стратегії формування агрокластерів у забезпеченні розвитку сільського господарства в Україні. Вісник ХДУ. Серія «Економічні науки». 2019. № 34. С. 23-26. https://doi.org/10.32999/ksu2307-8030/2019-34-4.

16. Berdiyev A. H., Dustova M. K., Musaev M. S. Advantages of introducing agrocluster in agriculture. International Journal on Orange Technologies. 2020. Vol. 2. Is. 11. Pp. 37-40. https://doi.org/10.31149/ijot.v2i11.860.

17. Kniaz S., Farat O., Bochko O., Stoianovskyi A. et al. Review and analysis of cluster development theories as an economic and managerial phenomenon. Proceedings of the 35th International Business Information Management Association (IBIMA), (Seville,1-12 April 2020). Pp. 1250-1256.

18. Kniaz S., Farat O., Merezhko N., Kozhushko L. et al. Managing the Competitiveness of Innovation Clusters. Proceedings of the 35th International Business Information Management Association (IBIMA), (Seville, 1-12 April 2020). Pp. 1257-1262.

19. Kniaz S., Shchebel A., Mrykhina O., Pavlenko O. et al. Factor analysis of the rationality of enterprise potential management in the coordinate system of organizational development. Arctic Journal. 2020. Vol. 73. Is. 9. Pp. 2-27.

20. Kniaz S., Stasishyn S., Rusyn-Hrynyk R., Myroshchenko N., Rozmarina A., Holovina O., Bets M., Halayko N. Monitoring of business structures: criteria and 
indicators. Proceedings of the 34th International Business Information Management Association (IBIMA), (Madrid, 13-14 November 2019). Pp. 6041-6048.

21. Князь С. В. Георгіаді Н. Г., Богів Ю. С. Бізнес-планування інноваційних проектів: сутність технології, переваги та недоліки. Маркетинг $i$ менеджмент інноващій. 2012. Вип. 2. С. 99-207.

22. Васільєва Л. М. Теоретико-прикладне трактування ролі кластера як інструменту підвищення конкурентоспроможності аграрного сектора економіки. Інвестииії: практика та досвід. 2011. № 23. С. 119-121.

23. Comberg C., Velamuri V. K. The introduction of a competing business model: the case of eBay. International Journal of Technology Management. 2017. vol. 73. No. 1-3. Pp. 39-64. https://doi.org/10.1504 / IJTM.2017.10003240.

24. Ren Y., Skibniewski M. J., Jiang S. Building information modeling integrated with electronic commerce material procurement and supplier performance management system. Journal of Civil Engineering and Management. 2012. Vol. 18. No. 5. Pp. 642-654. https://doi.org/10.3846/13923730.2012.719835.

25. Vdovenko N., Baidala V., Burlaka N., Diuk A. Management mechanism of agrarian economic system: composition, functions and factors of development in Ukraine. Problems and Perspectives in Management. 2018. Vol. 16. Is. 2. Pp. 179189. https://doi.org/10.21511/ppm.16(2).2018.16.

26. Prause L., Hackfort S., Lindgren M. Digitalization and the third food regime. Agriculture and Human Values. 2020. https://doi.org/10.1007/s10460-020-10161-2.

27. Шубравська О., Прокопенко К. Вплив українських сільськогосподарських корпорацій на національний торговий баланс. Економіка $\begin{array}{llll}\text { та прогнозування. } 2020 . & \text { Вип. } 1 .\end{array}$ https://doi.org/10.15407/eip2020.01.111.

28. Monastyrnaya E., Le Bris G. Y., Yannou B., Petit G. A template for sustainable food value chains. International Food and Agribusiness Management

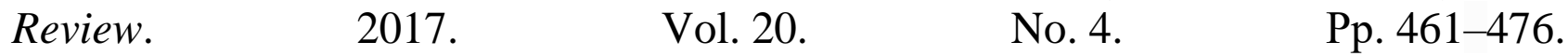
https://doi.org/10.22434/IFAMR2015.0061.

29. Будник О. Теоретико-методологічні засади кооперативного маркетингу в агробізнесі. Agricultural and Resource Economics. 2018. Vol. 4. No. 4. Pp. 85-98. https://doi.org/10.22004/ag.econ.281762.

30. Zatonatska T., Rozhko O., Tkachenko N. Modern trends of impact on economic development of countries: e-commerce and R\&D. Marketing and Management of Innovations. 2018. Is. 4. Pp. 129-135. http://doi.org/10.21272/mmi.2018.4-12.

31. Saban Kumar K. C., Arun Kumar Timalsina P. A case study on agro-based e-commerce portal. International Journal of Environment Agriculture and Biotechnology. 2018. $\quad$ Vol. 3. $\quad$ No. 1. $\quad$ Pp. 213-216. https://doi.org/10.22161/ijeab/3.1.27.

\section{References}

1. Farat, O. (2019), Teoretyko-metodolohichni pidkhody do zabezpechennia konkurentospromozhnosti sub'iektiv pidpryiemnytstva na zasadakh rozvytku 
innovatsiinykh klasteriv [Theoretical and methodological approaches to ensuring the competitiveness of business entities on the basis of the development of innovation clusters], Vyd-vo Lvivskoi politekhniky, Lviv, Ukraine.

2. Farat, O. and Bets, M. (2018), Formation of the information support for the entities of management by the development of innovation clusters. Baltic Journal of Economic Studies, vol.4, no. 2, pp. 249-253. https://doi.org/10.30525/22560742/2018-4-2-249-253.

3. Farat, O. and Lyvdar, M. (2019), Elaboration of technology for implementing of organizational solutions on the innovative clusters development. Baltic Journal of Economic Studies, vol. 5, no. 3, pp. 207-212. https://doi.org/10.30525/22560742/2019-5-3-207-212.

4. Audretsch, D. B. and Feldman, M. P. (1996), Innovative clusters and the industry life cycle. Review of Industrial Organization, no. 11, pp. 253-273. https://doi.org/10.1007/BF00157670.

5. Galvin, P. (2019), Local government, multilevel governance, and cluster based innovation policy: economic cluster strategies in Canada's city regions. Canadian Public Administration, vol. 62, is. 1, pp. 122-150. https://doi.org/10.1111/capa.12314.

6. Johansen, F. R., Kerndrup, S., Andersson, G. and Rubach, S. (2020), A view of clustering as emergent and innovative processes. Industry and Innovation, vol. 27, is. 4, pp. 390-460. https://doi.org/10.1080/13662716.2020.1718618.

7. Kinash, I., Andrusiv, U., Golovnia, O. and Popadynets, I. (2019), Aspects of the formation and development of innovation infrastructure in Ukraine. Management Science Letters, vol. 9, pp. 2403-2414. https://doi.org/10.5267/j.msl.2019.7.015.

8. Hermans, F., Geerling-Eiff, F., Potters, J. and Klerkx, L. (2019), Publicprivate partnerships as systemic agricultural innovation policy instruments assessing their contribution to innovation system function dynamics. NJAS Wageningen Journal of Life Sciences, vol. 88, pp. 76-95. https://doi.org/10.1016/j.njas.2018.10.001.

9. Akullo, D., Maat, H. and Wals, A. E. J. (2019), An institutional diagnostics of agricultural innovation; public-private partnerships and smallholder production in Uganda. NJAS - Wageningen Journal of Life Sciences, vol. 84, pp. 6-12. https://doi.org/10.1016/j.njas.2017.10.006.

10. Alroy, J. (2019), Discovering biogeographic and ecological clusters with a graph theoretic spin on factor analysis. Ecography, vol. 42, is. 9, pp. 1504-1513. https://doi.org/10.1111/ecog.04464.

11. Popkova, E. G., Shakhovskaya, L. S., Abramov, S. A. and Natsubidze, A. S. (2016), Ecological clusters as a tool of improving the environmental safety in developing countries. Environment, Development and Sustainability, no. 18, pp. 1049-1057. https://doi.org/10.1007/s10668-015-9685-3.

12. Stoianets, N. (2017), Regional clusters as a structural link sustainable development national economy. Agricultural and Resource Economics, vol. 3, no. 2, pp. 132-144. https://doi.org/10.22004/ag.econ.260672. 


\section{Agricultural and Resource Economics: International Scientific E-Journal}

http://are-journal.com

13. Bihus, M. M. and Holikova, Ye. D. (2017), Clustering as a perspective for the development of the international tourism and economy driver in Ukraine. Scientific Bulletin of UNFU. Economic Series, vol. 27, no. 2, pp.48-52. https://doi.org/10.15421/40270209.

14. Wardhana, D., Ihle, R. and Heijman W. (2017), Agro-clusters and rural poverty: a spatial perspective for West Java. Bulletin of Indonesian Economic Studies, vol. 53, is. 2, pp. 161-186. https://doi.org/10.1080/00074918.2017.1298722.

15. Artemenko, D. (2019), Strategies for agricultural formation in providing agricultural development in Ukraine. Scientific Bulletin of Kherson State University. Series «Economic Sciences», no. 34, pp. 23-26. https://doi.org/10.32999/ksu23078030/2019-34-4.

16. Berdiyev, A. H., Dustova, M. K. and Musaev, M. S. (2020), Advantages of introducing agrocluster in agriculture. International Journal on Orange Technologies, vol. 2, is. 11, pp. 37-40. https://doi.org/10.31149/ijot.v2i11.860.

17. Kniaz, S., Farat, O., Bochko, O. and Stoianovskyi, A. et al. (2020), Review and analysis of cluster development theories as an economic and managerial phenomenon. Proceedings of the 35th International Business Information Management Association (IBIMA), 1-12 April 2020, Seville, Spain.

18. Kniaz, S., Farat, O., Merezhko, N. and Kozhushko, L. et al. (2020), Managing the Competitiveness of Innovation Clusters. Proceedings of the 35th International Business Information Management Association (IBIMA), 1-12 April 2020, Seville, Spain.

19. Kniaz, S., Shchebel, A., Mrykhina, O., Pavlenko, O. et al. (2020), Factor analysis of the rationality of enterprise potential management in the coordinate system of organizational development. Arctic Journal, vol. 73, is. 9, pp. 2-27.

20. Kniaz, S., $\quad$ Stasishyn, S., $\quad$ Rusyn-Hrynyk, R., $\quad$ Myroshchenko, N., Rozmarina, A., Holovina, O., Bets, M., Halayko, N. (2019), Monitoring of business structures: criteria and indicators. Proceedings of the 34th International Business Information Management Association (IBIMA), 13-14 November 2019, Madrid, Spain.

21. Knyaz, S. V., Georgiadi, N. G. and Bogiv, Y. S. (2012), Business planning innovative projects: the essence of technology, advantages and disadvantages. Marketing and Management of Innovations, vol. 2, pp. 99-207.

22. Vasilieva, L. M. (2011), Theoretical and applied interpretation of the role of the cluster as a tool to promote the competitiveness of the agricultural sector of the economy. Investytsiyi: praktyka ta dosvid, no. 23, pp. 119-121.

23. Comberg, C. and Velamuri, V. K. (2017), The introduction of a competing business model: the case of eBay. International Journal of Technology Management, vol. 73, no. 1-3, pp. 39-64. https://doi.org/10.1504 / IJTM.2017.10003240.

24. Ren, Y., Skibniewski, M. J. and Jiang, S. (2012), Building information modeling integrated with electronic commerce material procurement and supplier performance management system. Journal of Civil Engineering and Management. vol. 18, no. 5, pp. 642-654. https://doi.org/10.3846/13923730.2012.719835. 
25. Vdovenko, N., Baidala, V. and Burlaka, N. and Diuk, A. (2018), Management mechanism of agrarian economic system: composition, functions and factors of development in Ukraine. Problems and Perspectives in Management, vol. 16, is. 2, pp. 179-189. https://doi.org/10.21511/ppm.16(2).2018.16.

26. Prause, L., Hackfort, S. and Lindgren, M. (2020), Digitalization and the third food regime. Agriculture and Human Values. https://doi.org/10.1007/s10460-02010161-2.

27. Shubravska, O. and Prokopenko, K. (2020), The influence of Ukrainian agricultural corporations on the national trade balance. Economics and forecasting, vol. 1, pp. 111-127. https://doi.org/10.15407/eip2020.01.111.

28. Monastyrnaya, E., Le Bris, G. Y., Yannou, B. and Petit, G. (2017), A template for sustainable food value chains. International Food and Agribusiness Management Review, vol. 20, no. 4, pp. 461-476. https://doi.org/10.22434/IFAMR2015.0061.

29. Budnyk, O. (2018), Theoretical and methodological foundations of cooperative marketing in agribusiness. Economics of Agriculture and Resources: International Scientific Electronic Journal, vol. 4, is. 4, pp. 85-98. https://doi.org/10.22004/ag.econ.281762.

30. Zatonatska, T., Rozhko, O. and Tkachenko, N. (2018), Modern trends of impact on economic development of countries: e-commerce and R\&D. Marketing and Management of Innovations, is. 4, pp. 129-135. http://doi.org/10.21272/mmi.2018.4-12.

31. Saban Kumar, K. C. and Arun Kumar Timalsina, P. (2018), A case study on agro-based e-commerce portal. International Journal of Environment Agriculture and Biotechnology, vol. 3, no. 1, pp. 213-216. https://doi.org/10.22161/ijeab/3.1.27.

\section{Citation:}

Стиль-ДСТУ:

Сумець О., Князь С., Георгіаді Н., Фарат О., Скриньковський Р., Мартинюк В. Методичний підхід до вибору варіантів забезпечення конкурентоспроможності підприємств у системі розвитку агрокластерів. Agricultural and Resource Economics. 2021. Vol. 7. No. 1. Pp. 192-210. https://doi.org/10.51599/are.2021.07.01.10.

$$
\text { Style-APA: }
$$

Sumets, A., Kniaz, S., Heorhiadi, N., Farat, O., Skrynkovskyy, R. and Martyniuk, V. (2021), Methodical approach to the selection of options for ensuring competitiveness of enterprises in the system of development of agricultural clusters. Agricultural and Resource Economics, vol. 7, no. 1, pp. 192-210. https://doi.org/10.51599/are.2021.07.01.10. 